\title{
NEW STRATEGIES FOR RURAL DEVELOPMENT IN THE RUSSIAN NORTH
}

\author{
Tamara Semenova ${ }^{1}$
}

Received 23 June 2011; Accepted 23 March 2012

\begin{abstract}
Rural landscapes in Russia cover a wide and diverse geographic area. The new economic reality established since the late 1990s aggravated the polarity in the urban/rural dichotomy and significantly modified both land use patterns and landscapes. Economic factors force governmental bodies and public authorities to pay special attention to the regions with specific development needs, to be addressed with a cross-cutting approach and to be mainstreamed into the strategic planning. Case studies of rural settlements in the Arkhangelsk region give evidence to these developmental trends. Traditional rural communities in the Russian North suffer from unemployment, depopulation, poverty and anomie. Loss of human capital puts forward the urgent development issues: capacity-building for the civil society and civic participation, self-government and law enforcement, social service and financial support, traditional land use and heritage preservation. Landscape policy becomes both a political and economic issue to be integrated through information exchange and communication into the planning and development process by local communities and their civic organizations.
\end{abstract}

Key words: rural landscapes, functional approach, sustainable development, strategic planning, Arkhangelsk, Northern Russia

Реферат: Сельские районы в России занимают обширные территории с различными природными условиями. Новый экономический порядок, установившийся с конца 1990-х гг., усилил поляризацию между сельскими и городскими районами и в значительной мере повлиял как на порядок землепользования, так и на ландшафты. Экономические фракторы вынуждают местные власти и правительство уделять особое внимание тем регионам, которые нуждаются в специальных мерах стимулирования развития. Необходимо, чтобы эти подходы могли результативно использоваться в стратегическом планировании. Модельные полевые исследования сельских поселений в Архангельской области подтверждают влияние самоорганизации населения на процессы местного развития. В традиционных сельских сообществах Русского Севера остро стоят проблемы безработицы, оттока населения, бедности и апатии. Потери человеческого капитала выдвигают такие неотложные задачи как развитие гражданского общества и самоуправления, активизация участия населения в принятии решений и соблюдение законов, наличие социальных

\footnotetext{
${ }^{1}$ Tamara Semenova, Senior Researcher, Russian Research Institute for Cultural and Natural Heritage named after Dmitry Likhachev, 2 Kosmonavtov street, Moscow 129366, Russia, Email: tams@online.ru
} 
служб и фринансовой поддержки, традиционное землепользование и охрана наследия. Ландшафтная политика становится политическим и экономическим фрактором и посредством информационных обменов и коммуникации, осуществляемых местным населением и его общественными организациями, становится частью процесса планирования и развития.

\section{Introduction}

In the heavily populated and industrialised Western society heritage is endangered by mass tourism, resource exploitation and commercialisation, whereas in the Russian context a number of regions experience little, if any, development. The social base for rural projects is reduced due to lack of investments, infrastructure and job opportunities, and consequent outmigration and depopulation.

Russia has been struggling for an appropriate infrastructure to elaborate and apply environmental conservation policy, suffering from government and public indifference to the heritage issues, including institutional deficiency in this field. The country has just recently initiated research into heritage conservation and no significant progress has been made in developing any original methods for heritage evaluation and monitoring. This is aggravated by the fact that the Russian heritage and landscapes are traditionally valued for their aesthetic, ethical and even spiritual qualities, rooted in the national and religious history. Educational, economic and commercial values are still neglected, and available heritage conservation projects fail to focus on the above factors. A beneficial effect is exerted by the acceptance and application of the Western concept of cultural landscape and practical investigations since early 1990 s in the different regions and heritage sites. However, historically these studies inherited the instruments and notions of physical geography as the leading national landscape science with a focus on landscapes as 'complex natural territorial units'. This makes the national concept of the cultural landscape quite original and distinct from the Western understanding.

Another factor is that the traditional rural landscapes in Russia are still existent, preserving the archaic forms of nature conservation, subsistence economy and traditional management. In remote areas, especially in the North, Siberia, Asian and Far Eastern regions, rural heritage includes actual agricultural techniques, traditional cultures, social and spiritual practices of the pre-Soviet and pre-industrialized era. Therefore, the living heritage of traditional communities is in need of both preservation and development, which calls for quite a peculiar combination of standard conservation measures. Importantly, the multinational Russia with a wide variety of ethnic groups, including indigenous peoples, requires a specific ethnic dimension in the rural heritage preservation.

The last, but not the least factor is the trajectory of development: in Russia there has been historically developed and still exist some negative socio-economic trends such as extensive and non-rational use of natural resources. In fact, in the Soviet society the owners/users of the land and resources were state enterprises that are nowadays transformed into private companies and state corporations. Some other negative trends are sub-urbanization and lack of the environmental awareness among the decision-makers. A new negative factor since late 1990 s is a decline of rural production and agriculture. Suburban areas and environmentally most attractive zones see an on-going process of chaotic land privatization for cottage construction, aggravated by legal misconduct in the land use. In these conditions researchers are to perform an important task of elaboration of practical skills and organizing specific actions to stimulate civic activities in area conservation and enhancement. Landscape can be seen as an interface between rural culture and ex-urban governance, and can serve as a means to settle conflicts between them.

\section{Rural Characteristics}

Transformation of the rural areas in Russia is primarily associated with the major economic changes since the Perestroika. Essential structural shifts occurred in the national economy: the portion of rural population employed in the agriculture, forestry and fisheries decreased from 
48 percent (in 1992) to 27 percent (in 2009). During the same period, the number of employees in commerce and service increased more than twofold, reaching 13 percent, whereas finance and management employed 15 percent of population, transport and communication 7 percent. However, agriculture remains the dominant sphere of production and employment in the vast majority of rural areas, and this sector epitomizes the rural economy. This is explained by a relatively low labour productivity in agriculture - it still lags behind western rural economy and, according to various estimations, is $8-10$ times less productive (Concept..., 2010 ${ }^{2}$ ). As a result, neither investments, nor alternative sectors can compete with agriculture.

The life standards in rural areas are low, and the sharp disproportion between the urban and rural living standards has been increasing. While in 1997 average resources of the rural households reached 69 percent of the urban level, in 2009 this index amounts to only 61 percent. Poverty is a common feature, it is concentrated in rural areas, accounting for as many as 42 percent of total low-income population in Russia in contrast to only 27 percent of rural residents in the country (Concept..., 2010).

What are the current trends in rural development? Among the most negative trends increasing unemployment is of importance (due to degradation of the kolkhozes and agricultural enterprises), loss of incomes, poor quality of the local services, safety degradation, environmental pollution, loss of population (in particular, departure of young people). Other (not necessarily negative) changes comprise change in lifestyle, invasion of cottage (second house) owners, immigration and development of new population strata; re-distribution of the local property; instability of local income; arrival of commerce and trade, exploitation of natural resources. Positive trends include access to resources and land, self-government, self-reliance, revival of subsistence economy, organic farming, better communication and transportation, infrastructure development, additional sources of income etc.

\section{Functions and Resources}

Russia's territory exceeds 17 million square $\mathrm{km}$, and approximately 23 percent of this area is occupied by agricultural lands. Population of the rural areas is 38 million people, comprising 27 percent of the total national demographic resources. Labour resources are comprised by 23.6 million people, with average population density of 2.3 persons per square $\mathrm{km}$. There are over 155,300 rural settlements, among them more than 142,200 have permanent residents. The majority of rural settlements are small-sized, with 72 percent having less than 200 residents, and only 2 percent of all settlements having more than 2,000 residents (Concept, 2010). The recent census in 2010 has revealed significant increase in number of abandoned or depopulated settlements (with less than 10 permanent residents).

Rural areas as a social and spatial subsystem execute multiple functions at various levels of the national economy (see Table 1). In some cases these functions are operational parts of the national and world systems.

Some of the functions in the rural areas are expanded - for example, traditionally products from the rural settlements simply end up at the local or regional market, but nowadays agricultural production can be globally distributed, especially in case of some unique or rare local products of food industry, raw resources for other industries, timber, hunting and fishing economies, nonagricultural production. In general, productive and demographic functions are the most important in the rural area, but at present there are other functions that become competitive in the long run - including functional services in the environmental protection, tourism and recreation, infrastructure and communication development, cultural (re)production and activities. The new political function - in local self-government sphere is still very modest, but it has a potential to ensure the establishment of the good governance models and through

\footnotetext{
2 Concept of Sustainable Development of the Rural Territories in the Russian Federation (until 2020) adopted by the Decree of the Russian Federation Government on 30 November 2010, No.2136-p (in Russian); www.gov.ru/2011035.doc
} 
a deliberate bottom up process reach the national level. Some of the functions of rural areas may extend to a global level, for example, if a specific rural site is inscribed on the World Heritage List or provides some services for the unique sightseeing or tourist attractions etc. Environmental and cultural functions are of specific interest in this context because they provide a much-desired impetus to rural economy in transition.

\begin{tabular}{|c|l|l|l|}
\hline No. & Traditional functions & Modern functions & $\begin{array}{l}\text { Level of functional } \\
\text { activity (old, new) }\end{array}$ \\
\hline 1 & Production & Production & $\begin{array}{l}\text { Local, regional, national, } \\
\text { global }\end{array}$ \\
\hline 2 & Demographic & Demographic & $\begin{array}{l}\text { Local, regional, national } \\
\text { international }\end{array}$ \\
\hline 3 & Labour resource & Labour resource & Local, regional \\
\hline 4 & Living and housing & $\begin{array}{l}\text { Permanent living and housing, } \\
\text { seasonal living and second } \\
\text { housing }\end{array}$ & $\begin{array}{l}\text { Local, regional, national, } \\
\text { international }\end{array}$ \\
\hline 5 & Communication & Communication & $\begin{array}{l}\text { Local, regional, national, } \\
\text { global }\end{array}$ \\
\hline 6 & Territorial control & Spatial control and monitoring & $\begin{array}{l}\text { Local, regional, national, } \\
\text { international }\end{array}$ \\
\hline 7 & Infrastructure & Infrastructure & Local, regional, national \\
\hline 8 & Social & Social & Local, regional, global \\
\hline 9 & & Environmental & Regional, national \\
\hline 10 & & Tourism, recreation & $\begin{array}{l}\text { Local, regional, national, } \\
\text { international }\end{array}$ \\
\hline 11 & & Cultural & Local \\
\hline 12 & & Political & \\
\hline
\end{tabular}

Tab 1. Changing Functions of the Rural Areas in Russia.

In addition to functional characteristics, a method based on the resource and factor analysis could be used for identifying priority measures to be taken in the depressive rural regions. Some major factors include: social activity, educational and environmental, as well as governance spheres. Major resources incorporate labour force, capital investments and assets, funding and natural resources, including landscapes. This method of quality evaluation is targeting maximum flexibility and possible modifications in the further research. Classification based on these indices proved instrumental in distinguishing four groups of rural settlements: socially stable and progressive, developing, resourceful and depressive rural settlements. These settlement types are associated with different evolution trends for the rural landscape (Semenova, 2010).

\section{Sustainable development}

In the recently adopted national "Concept of Sustainable Development for Rural Areas" sustainable development is defined as "a stable social and economic development of the rural areas, increase in production of the agricultural and fishery enterprises, improved effectiveness of the agricultural and fishery production complexes, full employment of the rural population and rise in its living standards, as well as rational land use" (Concept, 2010, p.7). The economic priority is obvious, though both social and environmental dimensions are also present in this definition.

It is important that among the most persistent problems of the rural areas the one of poor development of civil society institutions is pointed out. Subsequently, the policy objectives include the following measures: development of local self-government and civil society institutions, establishment of all forms of cooperation, wider participation of the rural population 
in decision-making, in particular, on issues of access to natural resources (lands, water, forestland), social services and possible rural settlement development.

Unfortunately, this strategic document does not mention any landscape or land use provisions or requirements, and, hence, the landscape policy is still lacking. However, in the section on the cultural sphere one of the objectives is aimed at development of rural tourism and includes among the relevant activities restoration of the historic manor estates and important cultural, architectural and nature monuments, establishment of ethnographic complexes and construction of other rural infrastructure objects.

In the practical actions aimed at sustainable development project work is one of the most promising spheres, in particular, because it strengthens local initiatives and self-government. An open list of actions for project development in the rural area includes:

1) identification of the main stakeholders and institutions with various interests in rural areas;

2) definition of expectations, limitations and interests of these groups and institutions:

- local population (community leaders, activists, opportunists, young people, elders, other social groups),

- religious and clerical societies (Orthodox, other churches, indigenous peoples' traditions and beliefs, influence of external groups, education, mass media),

- national (ethnic) organizations and communities (NGOs, locals and immigrants, minorities etc.),

- economic associations (cooperatives, farms, economies etc.),

- territorial public self-governments,

- local administration, municipal authorities, local deputies, police etc.

- regional authorities,

- territorial governmental bodies of planning, development and control,

- territorial bodies for social welfare and protection,

- federal bodies (legal offices, protected areas, land and natural resource management, cultural monuments etc.),

- business community (companies, enterprises, holdings etc.),

- research and consulting groups (experts, scholars, amateurs in local lore, history etc.),

- others (e.g. general public, media, communication and tourist services etc.);

3) evaluation of resources and spheres for local development (spiritual and cultural, environmental, social, economic, legal, political and institutional);

4) identification of the objectives of spatial development (functional, territorial, network);

5 ) identification of the integral objectives (or programs) of rural development;

6) specification of the activities for cultural and natural heritage preservation and cultural landscape conservation during the project period;

7) initiation of the model projects for rural settlements development targeted at heritage and cultural landscape preservation and use;

8) identification of the channels for support of the model projects (through budgets and programs, sponsorship, foundations, legal advice and institutional support, stakeholders, business, scientific expertise, public and non-governmental organizations, management bodies and partnership agreements).

In the legal sphere and social programming there is a continuous reference to 'settlements' (poseleniya) not to 'communities' (soobschestva or obschiny), which is an obvious legacy of the Soviet period with the artificial separation of the management (top-down) and civic (bottom- 
up) culture. In the modernization process of the Soviet state the living culture and local community as the nucleus of economy were neglected and it is not until Perestroika that the local or ethnic identity of the remote and dispersed communities and their autonomy were able to revive along with mere physical survival under the acute economic crisis. In these conditions, the knowledge on landscape (and spatial structure and resources in general) and community mobilization became the main asset capable of triggering the local economy transformations. The post-modern economy requires strong impulses from the local population for self-development to be incorporated into the global community, and economists claim that it requires not only knowledge but also exchange of knowledge through omnipresent information networks (Pilyasov, 2006).

Also of importance are spatial management skills that are still governing the rural territory through the customary law, and also the process of introduction of new legislation, in particular, the Federal Law 131 "On General Principles of Organization of the Local Self-Government" does not take into consideration the existing governance structures and entities, ignoring the realities of the provincial life (see Materials on Discussions in the Public Chamber, 2008). However, the rural landscape playing the role of social space, manifesting various models of spatial development, i.e. time and space is adequately reflected in a specific type of cultural landscape. However, in totalitarian periods the approach towards spatial development in different societies is similar, being manifested in power relations with the nature, i.e., a 'conquest' by man, and violent transformation of space. In the imperial society there emerges a new organization of the territory - a sacred, highly cultivated center opposing the vast exploited but neglected periphery. The same applies to Soviet rural and provincial areas - they were treated as obsolete, retarded territories in the way to the more 'progressive' urban social space. In this function existing rural landscape was symbolically deprived of its traditional meaning and value, its most important elements destroyed, and its territory re-developed as the 'virgin' land. This approach has been prevailing in the northern areas - the oil and gas companies have been treating indigenous lands as unsettled, 'no-man' territory, where the nation-state represents the 'supreme interests of the nation' simultaneously depriving native communities of any rights to their social and spatial forms of life and their resources of the habitual environment.

Landscape degradation is a very dangerous social process, as in a traditional community the cultural landscape manifests three aspects of the spiritual life as follows: conceptual reflection of the common meanings and worldview, spiritual - reflection of the moral standards, and behavioral - reflection of the accepted ethical standards. These three aspects correspond to the respective functions of the cultural landscape: traditional world order, communication and regulation. In the period of social transformations transfer of cultural traditions requires reinterpretation of the old symbols, values and norms for heritage preservation. According to Kolbowsky (2008), the cultural landscape represents the collective memory in the forms of human interaction with the nature.

\section{Strategic Planning}

In addition to the conceptual work at the national level and establishment of the federal programs, the government assists in planning at the regional and local levels in the form of seminars for municipal bodies. They target at the development of the strategic plans for socialeconomic development in the municipal districts and rural settlements. Municipal bodies are further responsible for elaboration and adoption of their specific programs for social and economic development (according to the Federal Law 131, article 17, $\S 1^{3}$ ) Normally, such programs include the following chapters:

- social and economic analysis of the municipal territory,

- identification of the key problems to be solved for effective development,

- strategies for the municipal social and economic development aimed at the solution of the key problems,

\footnotetext{
${ }^{3}$ http://www.rg.ru/2003/10/08/zakonsamouprav.html
} 
- elaboration of the set of projects for each of the strategic directions (including business development plans),

- definition of the parameters/indicators for program monitoring and control.

Strategic planning process is also helpful providing information exchange and communication between the community members, governmental, non-governmental and business (market) networks. Local community actions aimed at the active exchange of the internal and external knowledge, improvement and intensification in the information exchange are able to remove communication barriers, and thus accelerate local development. In this respect, according to Pilyasov (2006), three types of the Russian provincial communities can be distinguished as follows:

- first, the remote, seasonally accessible settlements in the North, Siberia and Far East regions. They pertain to the extensive zone of the natural and social isolation. The body of local and creative knowledge available is relatively small here, but external imported formal knowledge (technologies of industrial companies) dominates;

- second, the enclaves, where local communities are isolated for various reasons (rapid ageing of the population, emigration of younger people, exodus of educated and knowledgeable members) are located primarily in the European part of Russia. The body on of local knowledge available is rather large there due to the long history of the communities and their environmental skills;

- third, ethnic, confessional or indigenous isolates, where community members are living in small-numbered groups either in spacious areas, or among other nations and populations. The portion of traditional and local knowledge is highest in such communities.

During the planning process assessment of the social resources ensures consideration of intangible reserves of the community through the quality estimation of social relations, communication and available institutions. This assessment might help to improve interaction between the authorities and management bodies of different levels for community and spatial development.

Strategic planning is gradually involved in environmental protection activity, though there are no yet instruments available for adequate consideration of the landscape development processes in modern Russia. At the same time, landscape planning is a prerequisite component of spatial planning, and in the Soviet time there existed an excellent Territorial Comprehensive Plan for Nature Protection (TERKSOP), elaborated for regional and local administrations by professional planners and academics. Until the 1990s the tasks of spatial planning were carried out by a system of territorial master plans, and the main functions of strategic planning were assigned to the State Committee for People's Economy Planning (GOSPLAN). Today, only special boards under regional administrations within the government of the Russian Federation, some of the municipalities and commercial design companies are engaged in spatial planning. In addition to the deficit of system approach and transfer of professional skills, there is no regulation or only fragmented or poor legal framework available. There are two regulatory documents for construction and land use available as follows: the Urban Planning and Land Codes of the Russian Federation. Landscape planning is of special importance to the rural areas, because the majority of rural municipal regions remain subsidized and their investment opportunities may be dependent on the attractiveness of the natural conditions and landscapes or the various land use options.

Spatial planning of the rural areas is more promising. Analysis of the spatial structure of the presently depressed territories demonstrates a need to combine economic feasibility with preservation of natural environment. Based on such strategy for spatial development, landscape planning can ensure sustainable development of the rural areas (Romanova et al., 2004).

\section{Governance and Self-Government}

According to Yanitsky (2002), the Russian state today is trying to neutralize the emission of social degradation energy by increasing the power defensive structures (as the army, police 
etc.) and by strengthening the vertical structure of the executive power. The latter process naturally has been reducing the self-organization opportunities in the bottom up direction, and thus is weakening the civic activity and self-government at the local level. In modern Russia there are many places where local people are jointly working for improvement of the life standards and housing conditions; and the authorities, businessmen and local population jointly make great efforts for capacity-building, municipal economy growth, private property improvement, nature and monuments protection and other spatial activities useful for local development. Unfortunately, this much needed cooperation is very often lacking in rural areas due to the lack of trust, organizational and professional capacity and other reasons.

It is well known that there are two main governance models: the European and Anglo-Saxon. In the former case, the local authorities represent the bottom level in the state power subordinated by the hierarchical upper levels of the authorities. In the latter case the local self-government system is excluded from the governmental power structure and to some extent, being formed by citizens and pursuing their interests, opposes the state. According to the recent sociological surveys in Russia (Nikovskaya, 2009), the majority (51\%) of respondents support the latter model and only $32 \%$ are inclined to accept the 'vertical subordination' model. It is misfortunate, as this lack of trust inherited from the Soviet period prevents communication with the state and governmental authorities and endangers cooperation for development both outside and inside the rural community.

Self-government in Russia is regulated by the Federal Law 131 adopted in 2003. The major novelty of this Law is the territorial and administrative delimitation. In fact, there are rigid and meticulously identified borders of all three types of the municipalities - urban and rural settlements, municipal districts clustering rural settlements, and independent city districts which are not incorporated into the municipal districts. This delimitation was supposed to be executed until 2006, but the majority of the municipalities were not able to formally fix their borders until as late as 2010. Historically, many of the cities are interconnected with their provincial areas and economically can even support the federal region as a whole (such cities as Norilsk, Tyumen etc.). Based on this newly introduced delimitation, it is more difficult to integrate the common provincial cultural life, history and natural environment into fragmented administrative management. However, interest in transformation of the local governance in the country remains high. In 2002 President Putin said in his annual address to the Federal Assembly: "We should have improved our municipal legislation long ago. Though badly needed by our citizens in everyday life, this legislation remains substandard, overcomplicated and frequently illogical. To solve that problem practical administrators and experts in the municipal self-government, public unions of the Russia's cities and non-governmental municipal associations with theoretical and practical expertise are involved". In 2008 President Dmitry Medvedev also said: "Local self-government shall open opportunities for citizens to independently solve their local problems with no directives and orders from above". Both messages are appealing to the local community and formal and informal institutions to master their own life and manage lands and local environment for their vital needs (Parlamentskaya Gazeta, 2008, p.8).

Today, the implementing agency for the local self-administration at the governmental level is the Ministry for Regional Development ${ }^{4}$. It is this agency where European Landscape Convention is screened for optional signature by Russian Federation. The Committee of the State Duma on Local Self-government has been specifically established for elaboration of the topical legal acts. The legal basis of the local self-government was stated in the Russian Constitution adopted in 1993. But in further elaboration of this legislation the system of local self-government was established before the financial mechanism was fully introduced. At a later stage, too many amendments were made (35 previously adopted Federal Laws were enacted and amended in multiple instances!) and the Law 131 eventually enlarged its competence to the less coordinated and comprehensive content and form. Unfortunately, this Law is not an exception, for analysis of the heritage legislation in Russia (Kuleshova, 2007) reveals that

\footnotetext{
${ }^{4}$ www.minregion.ru
} 
a tendency of inadequate coordination of legal acts prevails in the legislature practice of the Russian State Duma.

To date, at least the budget has been approved for each municipal government. It was no easy task as the number of these institutions in 2009 increased to as high as 24,000 (in 2004 there were 11500 municipal bodies). Most of the changes in the Law 131 (in the Articles 5 and 6) are concerned with the division of the responsibilities (see Table 2), the rights and responsibilities of the head of the municipal government and economic regulations of the local self-government.

\begin{tabular}{|c|l|c|c|}
\hline No. Issues/sectional division & $\begin{array}{l}\text { Bodies of } \\
\text { governmental } \\
\text { power }\end{array}$ & $\begin{array}{l}\text { Bodies of local } \\
\text { self-government }\end{array}$ \\
\hline 1 & Political & 5 & 2 \\
\hline 2 & Legal & 6 & $\mathbf{0}$ \\
\hline 3 & Economic & 5 & 2 \\
\hline 4 & Territorial administration & 2 & 1 \\
\hline 5 & Life conditions, safety, development of the & $\mathbf{0}$ & 7 \\
\hline 6 & Environmental & $\mathbf{0}$ & 3 \\
\hline 7 & Land use & $\mathbf{0}$ & 2 \\
\hline 8 & Social and living standard & $\mathbf{0}$ & 1 \\
\hline 9 & Social & $\mathbf{0}$ & 4 \\
\hline 10 & Transport & $\mathbf{0}$ & 1 \\
\hline 11 & Cultural & $\mathbf{0}$ & 4 \\
\hline 12 & Information & $\mathbf{0}$ & 2 \\
\hline & Total: & $\mathbf{1 8}$ & $\mathbf{2 9}$ \\
\hline
\end{tabular}

Tab 2. Division of Responsibilities in the Governance Sphere (Nikovskaya, 2009).

What are the essential problems in the self-government? First, the local competence increased, but the implementation of these responsibilities is not sufficiently funded. Secondly, the majority of the municipal bodies are incapable of coping with the amount of work available, even if the financial situation is satisfactory.

The municipal reform and the policy of the local self-government cannot but reflect the general political trends of the state. It would be naïve to expect that self-government at the local level could evolve into more democratic and autonomous model after the election reform put an end to the governor competitions. But on the other hand, the institute of self-government gives much more liberty to decision-making at the local level and some of the institutions are more interested in operational activity for rural development.

One of such institutions, namely territorial public self-government, emerged in the Russian province in 1990ies. Vyacheslav Glazychev, the Chair of the Public Chamber Commission on Self-Government refers to these territorial self-management bodies (territorial'noe obschestvennoe samoupravlenie - TOS) as 'community-based' organizations (Glazychev, 2004). Indeed, self-governance initiatives spontaneously emerged in such distant areas as the Arkhangelsk region and Chukotka, Altai and Central Russian provinces. This process was most active in the remote areas with no immediate access to governmental funds or support. Those were attempts to revive the type of management genuine to the term 'landschaft' translated in mid-19th century from German into Russian as 'zemstvo' - the rural or provincial society with the authorized territorial self-management. In emerging capitalism 'zemstvo' in Russia played the same role as the self-governing legal entities in Europe (such as regions of Frisia and Jutland described by Kenneth Olwig, 2009).

These initiatives were lucky to get support from the western grants aimed at educating civil society on the new economic development. Though 'abandoned by the state', remote areas were still abundant in sufficient human and social resources, able to trigger local organizational development in the regions (Pilyasov, 1996). 
Local TOS activists were acting as effective transformers of local knowledge, traditions, and values into innovative development initiatives, including the landscape and heritage preservation. TOS plays an important role in local economy development via its activities as follows:

- initiation of enhancement of the cultural and natural heritage, its maintenance through use in everyday life;

- reference of major TOS initiatives to cultural life and traditional community functioning;

- self-organization of the local community aimed at independent decision-making to solve urgent problems;

- cooperation with the municipal self-government for elaboration of the local social and economic development programs;

- partnership with the municipal self-government body aimed at implementation of the specific projects on sustainable development at the community level.

Taking into consideration this role of TOS, it would be advisable to elaborate the comprehensive program on cultural and natural heritage preservation and enhancement in the regions where TOS continue to act as the model civic institutions. In order to further promote project activities on cultural landscape preservation it is necessary to provide legal, scientific and financial support to these organizations.

\section{Regional Case Study}

According to the recent evaluation of the development perspectives, state of economy and relevant regionalization of the Russia's territory (Nefedova, 2006) Arkhangelsk region is located in three zones: northern regions, i.e., in the un- or under-developed areas, in the major portion of the territory are forestlands, oil and gas fields and mineral resources deposits, whereas the southernmost narrow are forestlands and farmlands. In the first zone with only $2 \%$ of the total population dispersed over $48 \%$ of the total Russia territory, the most profitable mining industries (oil, gas, gold, diamond, nickel etc.) operate in the small settlements or big flourishing industrial cities, the rest of the territory being managed traditionally by indigenous people archaic reindeer herders, hunters and fishermen in remote and highly isolated communities.

The second zone contains small rural settlements along the river banks or on the seashore, where big cities predominantly are good harbours, ports or timber processing centers. Farming there is focal-patterned, practiced around built-up areas.

The third zone comprises major industrial cities with intense suburban agriculture and semiurban infrastructure, but the most important characteristic of this zone is a striking contrast between the big centers (usually historical cities) and the rest of the rural territory which is in the state of decay and economic decline. Due to recent depopulation in the rural areas and lack of investments, employment and adequate social support, the villages in the so-called 'nonchernozem' (agriculturally less productive soils) zone are rapidly disappearing and farmlands show natural re-forestation.

In these three zones extensive rural areas (being of specific interest to us) are reported as socially and economically depressive territories with very little, if any, potential for development.

To improve the situation, the Arkhangelsk regional authorities are doing their best to cooperate with the municipal bodies in search of development ideas and elaboration of comprehensive social and economic programs for all types of the municipalities (districts, cities, settlements). Regional government was instrumental to organize a series of seminars for municipal bodies to assist in the development of the strategic plans for socio-economic development in the municipal districts and rural settlements for 2-3 years. Clearly, the period concerned is brief enough, but in 2007 when seminars were held in the Arkhangelsk region, management training of the staff of the municipal bodies, in particular, newly established, was badly needed. In fact, a number of employees had no experience in developing planning documents, were not knowledgeable about the respective standards and lacked strategic planning skills. After 
working on these plans, by the end of 2009, eleven of the 26 municipal districts in Arkhangelsk region elaborated programs for social and economic development. Since then there are 179 rural and 24 smaller urban settlements in addition to 26 large municipalities, that form smaller municipal bodies in Arkhangelsk region, meeting legal requirements to adopt a comprehensive social and economic program (the requirement of Federal Law 131, clause 17, para 1) could be a long-term objective. A new web-portal (www.dvinainvest.ru) was launched in 2009 in the Arkhangelsk region to provide a common information resource and to ensure the Internet access to documents on economic regulations and available investment sites, ideas and projects, including innovations in the regional economy.

Recommendations for the sustainable development at the local level spatial planning include analysis of socio-economic conditions, external and internal trends of development, and also land use regulation process. Thus, it is possible to consider the system of spatial planning as part of both the strategic and the operative management of the place.

The culture factor has an important role to play in considering the external and internal approaches to regional or local development. Arkhangelsk region, the core area of the Russian North with the distinct medieval Pomor (sea-farer) culture, contains 1971 monument of architecture, history and culture, including 561 protected on the federal (national) level, and 1410 monuments of regional significance. Architectural monuments are by far dominant (1715 objects). The Solovetsky Islands Ensemble in the White Sea was registered in 1992 as the UNESCO World Heritage Site, representing an outstanding architectural and cultural monument of the ancient Orthodox monastery. Along with the other great architectural monuments a wooden church built in late 17 century in the Kimzha village (Mezen district of the Arkhangelsk region) was granted the status of national protected monument in mid20 century, but like many other cultural objects of the Russian North, it has been conserved for decades in the non-operational state and was excluded from both economic and cultural life of the residents.

However, our model research (2006-2010) in this rural settlement (Fig. 1) revealed that the operation of major (if not all) economic activities of the village population is based on living oral regulations and traditions in the community via maintained cultural environment and transfer of knowledge from the older generation to young people. This process was not interrupted in the Soviet period due to peripheral position of the rural areas in the highly centralized economic development programs. Formal and non-formal knowledge on spatial environment and local territory co-exists in the rural community along with the present-day ignorance of environmental sustainability and proliferation of the domestic garbage sites around the village. Acts of tradition violations also become more common with the infrastructural changes, in particular, when the car road eventually connected village with the district center and the regional capital city.

The new, innovative approach to preservation of the local lifestyle is connected with the attempts to establish some kind of protection regime on the territory of community, establishing a regional heritage site in accordance with the newly introduced legislation on the protection of cultural objects. The rather rare tourist visits to Kimzha in summer time are associated with a still exotic cultural tourism, and in attempts to attract more visitors and income to the village economy a local museum, cultural center in the village school, guest house were established, a peasant wind mill and the monumental wooden church were restored, and ancient cooking recipes were revived, and a folk choir and other tourist attractions were organized. This comparatively high potential for volunteer (or very scantily funded by humanitarian and cultural grants) activities is based on community interest and selforganization.

These activities are performed by native residents, capable of building up trust and relationship with the district and regional authorities, and with vital assistance from family and community members they continue a struggle for village development through its preservation. This is no easy task, with several factors threatening local initiatives.

${ }^{5}$ http://whc.unesco.org/en/list/632 


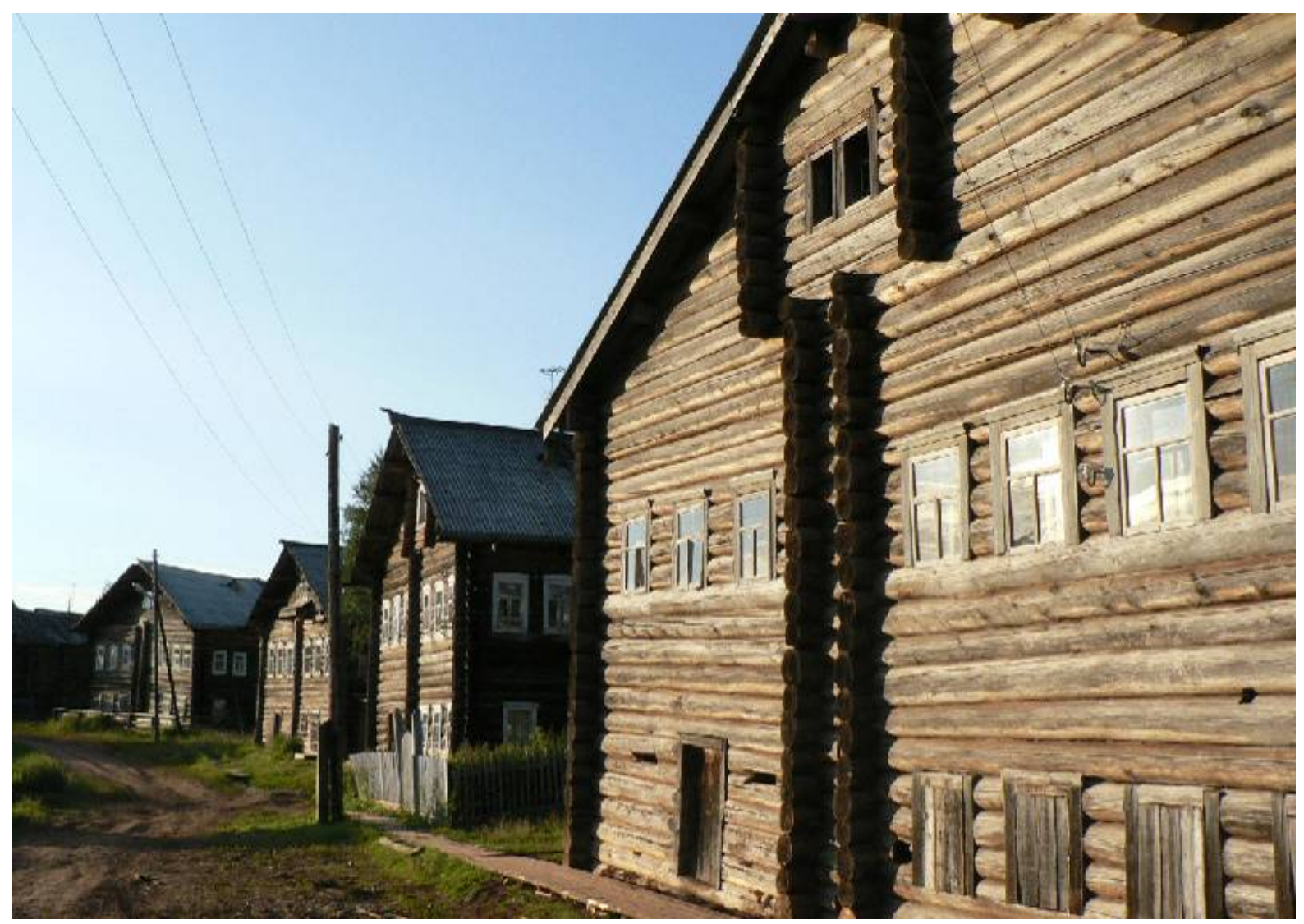

Fig 1. Old traditional houses in the village of Kimzha. Photo: Marina Kuleshova, 2004.

One factor is legal transformation - there is still lack of operational documents for both spatial and cultural management at the local level. The present situation with the territorial public selfmanagement in Arkhangelsk region is unstable: in some cases TOS have no legal statute and they prefer not to be registered as formal organizations. Concurrently, there is an opposite trend of establishing TOS for administration of the project funds allocated by the Regional Department of Culture. In rare cases competition for project funding generates situations with several TOS in one settlement or refusal of the local community (via TOS) to implement the initial project with the allocated grant money. By their legal status TOS are public, non-governmental organizations (specifically in the Arkhangelsk region where they have been initiated as early as in 1995), many leaders (chairs of TOS elected Council) participated in the elections in the local municipal bodies and were elected for administrative work in their native settlements (for example, in the Mezen district three of the former TOS chairs now are the heads of their local municipal bodies). Most importantly, the majority of the TOS continue to initiate and implement projects on culture and heritage preservation. For example, in Kimzha 10 TOS projects were successfully implemented, and new projects are being submitted for further activities in the sphere of cultural development.

Another negative factor is the on-going process of 'hidden privatization' of the land. It is an almost invisible process as public space in province is rarely physically invaded, but becomes economically unsustainable through legalization of the priority access or private rights to use the spatial resources, such as land, forestland, water bodies (ponds and reservoirs), wild plants, hunting animals etc. This on-going process of re-privatization in seemingly all spheres endangers some community rights and assets: local community is alienated from its own products - the public goods, spaces and heritage in a broad sense - where the cultural environment, including landscapes, is one of the perceived and recognized social values. 


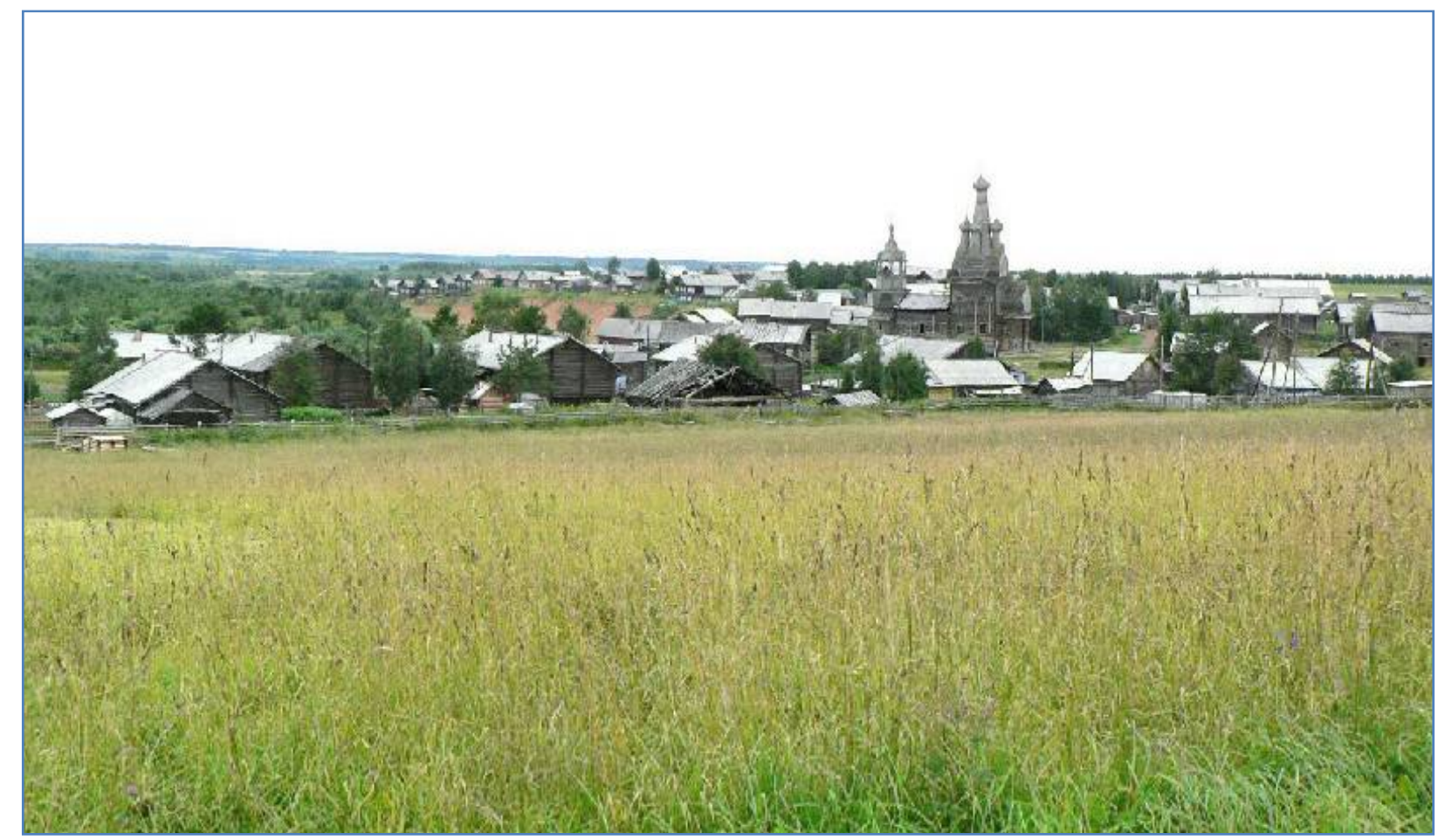

Fig 2. Kimzha cultural landscape - heritage site under consideration. Photo: Marina Kuleshova, 2004

A third threat is fragmentation of the land plots due to land privatization resulting in landscape disintegration and ecosystem dysfunction. In 1984 the Kimzha village was designated to be part of the regional museum-reserve incorporating also adjacent rural settlements of Kiltsa and Kozmogorodskoe. The latter has lost almost all wooden architecture monuments ever since. Therefore, now a new proposal is under consideration - establishment of the heritage site ('dostoprimechatel'noe mesto' according to the Federal Law $73^{6}$ ) covering dozens of thousand hectares around Kimzha settlement. It is living village with historic structure of the housing area, extensive agricultural lands, representing peasant cultural landscapes originated in 1617 centuries (Fig.2). Prior to establishing a heritage site it is necessary to elaborate the Statute on Heritage Monument at the local level and to ensure territorial delimitation of the site. But the legal documents are still lacking, and implementation of the law relating to this proposal is seriously hindered by the interests of the authorities in the large-scale investment projects with extensive spatial needs, such as agricultural complexes, construction, transportation and infrastructure development etc.

\section{Conclusion}

Russia after launching a swift modernization process is more prone to all risks of the world economy. In the situation of the risk society (Beck, 1992) strategic planning and knowledgebased economy is hindered, as the state is forced to respond to the emergency situations instead of investing into studies of the long-term processes and strategic planning, even if they are essential for the economic stabilization and social security.

In contrast to the industrial period, the post-modern development is based on culture organically incorporated into regional development. The relationship between culture and economy becomes more intense and stronger than in previous conditions: extensive resources of knowledge are rooted in local culture and traditions. Their revelation and creative reinterpretation along with the modern knowledge and technology is very often exceptionally productive for the local development. From these creative associations new development trajectories might successfully be launched.

\footnotetext{
${ }^{6}$ http://www.rg.ru/2002/06/29/pamjatniki-dok.html
} 
Rural periphery in opposition to the urban center has to overcome the present economic depression via alternative pathways. A number of former agricultural areas are trying to overcome the decline through tourism development, but the challenge is that tourism has a role to play within a more varied rural economy. A diversified economy alone ensures sustainable long-term care and maintenance of historic monuments, heritage sites and landscapes ${ }^{7}$.

The rural society, its local culture and environment are interconnected through the common law, and the cultural landscape is the representation of this relationship. The management plays an essential role in this process, and the local community proved to be very active in it, when the first territorial public self-management bodies (TOS) attempted to get control and management into own hands - by the local residents and their leaders. The genuine spatial governance exercised by these community-based bodies was naturally oriented at the community survival, and social and economic projects were of their primary concerns. But the initiatives in the sphere of culture played equally important role and were on par with the other civic actions. Projects with dominant cultural activities have been more frequently funded by foreign foundations and authorities and remain on the rural agenda longer than any other projects. It can be explained by the assumption that cultural survival and environmental conservation are the less conflict-prone spheres, but a recent case regarding international investments into highway construction near Moscow via Khimki Forest ${ }^{8}$ vividly demonstrated that local culture and landscape as a public sphere is becoming highly politicized and the government tries to put it under rigid control.

In the rural areas where majority of population and local community have no means for survival except the subsistence, a legal access to public space and to common natural and cultural resources play a decisive role. Though newly introduced term 'governance' has been translated into Russian as 'upravlenie'(control), in our opinion, this institution in practice has a chance to be operationalized only by self-government bodies at the local level.

At present, as the regional level managers justly report (Lapteva, 2010), the local communities and their civic organizations choose either passive opposition or counteraction instead of cooperation with any level of government, and this choice narrows the opportunities for public activity and local initiatives aimed at sustainable development. Mistrust really reigns in the governance sphere, aggravating economic and social decline in the rural areas. But the partnerships and coordination for the cultural landscape management are most essential. Cultural landscape, generated by its guardians in situ, could be preserved as a heritage site only in case of public recognition ex situ.

References

[1] Beck, U. (1992). Risk Society. Toward a New Modernity. London: Sage.

[2] Glazychev, V. (2004). Rossiya: printsipy prostransvennogo planirovaniya (Russia: Principles of Spatial Planning), Report published at personal website http://www.glazychev.ru/projects/2004_ProstRazv/2004_DocladProstRazv_oglav.ht.

[3] Glazychev, V. \& Genisaretsky, O. (1997). Razvitie mestnogo samoupravleniya I stanovlenie grazhdanskogo obschestva $\mathrm{v}$ Rossii (Development of the local selfgovernment and civil society in Russia), Gorodskoe upravlenie, No.5, Obninsk.

[4] Kolbowsky, E. (2008). Landshaftnoe planirovanie (Textbook on Landscape Planning), Moscow, Academia.

[5] Kuleshova, M. (2007). Landscape Heritage in Russian Legislation Today. In Landscape and Rural Heritage (pp. 149-156). Proceedings of the COE workshop Sibiu, Romania, 2021 September, 2007.

\footnotetext{
${ }^{7}$ http://precomos.org

${ }^{8}$ http://www.rusnovosti.ru/news/108918/
} 
[6] Lapteva, G. Ya (2010). K voprosu o sokhranenii kulturnogo naslediya (On Preservation of Cultural Heritage). Abstracts of Reports of the International Conference "Culture of the Wood- Wood in Culture". Moscow-Rostov Veliky, 24-28 September 2010, pp. 110-113.

[7] Nefedova, T. (2006). Uvidet' Rossiyu (Discovering Russia), Otechestvennye Zapiski, 6(5), 41-58.

[8] Nikovskaya, L. (2009). Mestnoe samoupravlenie: protivorechiya i problemy reformirovaniya $v$ Rossii (Local Self-Government: Contradictions and Problems of Reform in Russia) http://www.spravedlivo-online.ru/diskus/TSG/tsg.php?ELEMENT_ID=1573.

[9] Olwig, K. (2009). Landscape, Culture and Regional Studies: Connecting the Dots. In N. Castree, D. Demeritt, D. Liverman \& B. Rhoads, (eds.), A Companion to Environmental Geography (pp. 238-252). Oxford: Blackwell Publishing.

[10] Parlamentskaya Gazeta (Parliament Newspaper), 21 February 2008, № 10-11 (22622263), pp. 8-9.

[11] Pilyasov, A. (2006). I poslednie stanut pervymi (And The Last Will Be First), Otechesvennye Zapiski, 6(5), 8-25.

[12] Pilyasov, A. N. (1996). Zakonomernosti i Osobennosti Osvoeniya Severo-Vostoka Rossii: retrospectiva i prognoz (Conceptual and Specific Characteristics of the Russian North-East Development), Magadan: North-East Interdisciplinary Scientific Research Institute FEBRAS.

[13] Romanova, E. A., Vinogradova, O. L. \& Stanchenko, L. Y (2004). Structure and evolution of landscapes in connection with strategic planning of development of rural areas (on the example of the Slavsk area in the Kaliningrad district), Changing function of rural areas in the Baltic Sea region (pp.150-158), Warsaw: European rural Development Network.

[14] Semenova, T. (2010). Rural Landscape in Russia: Local Participation and Development Trends. Living Landscape (vol.2, pp.261-266). Conference materials, Florence, 18-19 October, 2010.

[15] Yanitsky, O. (2002). Rossiya: ekologichesky vyzov (Russia: Environmental Challenge), Novosibirsk: Sibirsky Chronograph. 